\title{
on education
}

Journal for Research and Debate

\section{editorial: academic lives}

\author{
On Education
}

\begin{abstract}
Academic life has changed dramatically in recent decades. With the expansion of higher education, broader sections of the population have gained access to colleges and universities. This has had a huge impact on the composition of students and higher education staff. Thus, the diversity of higher education institutions has increased significantly. However, gender, ethnicity and social background still strongly determine which fields of study are chosen and which careers are subsequently open to students inside and outside academia.
\end{abstract}

Keywords: academia, editorial

Academic life has changed dramatically in recent decades. With the expansion of higher education, broader sections of the population have gained access to colleges and universities (Schofer \& Meyer 2005; Labaree 2017). This has had a huge impact on the composition of students and higher education staff. Thus, the diversity of higher education institutions has increased significantly (Michalski, Cunningham \& Henry 2017). However, gender, ethnicity and social background still determine which fields of study are chosen and which careers are subsequently open to students inside and outside academia (Boliver 2011; Blossfeld, Blossfeld \& Blossfeld 2015).

As a result of this educational expansion, universities and colleges have grown significantly since the middle of the $20^{\text {th }}$ century. New universities and colleges have been founded and new disciplines created (Frank \& Gabler 2006; Mälzer 2016). In many cases, financing has not kept up with this expansion. As a result, the universities are either chronically underfinanced or they are opening up new sources of funding. The horrendous tuition fees and the growing influx of third-party funds in some countries bear witness to these problems and failures (Archibald \& Feldman 2010; Anderson 2016).

Last, but not least, the demands on those who want to pursue an academic career have changed. Compared to earlier times, more people are obtaining higher educational certificates. Not least for this reason, competition for rare permanent positions in the universities has increased massively (Powell 2015). Large-scale research funding initiatives and graduate programs have exacerbated this trend by producing more and more doctoral students with similar academic backgrounds (Cyranoski et al. 2011). High mobility expectations, the pressure to publish, expectations of good networking skills and uncertain future prospects are weighing on the young researcher. However, the systems differ considerably from country to country. National traditions, hybrids and new forms of organisation for academic career paths can be found side by side (Frølich et al. 2018).

In light of these and related developments, it has become increasingly difficult to make sense of academic life, its social and political functions, its purposes and core characteristics. The aim of this 
issue of on_education is to stimulate debates about the contemporary meaning of academic life by adopting a comparative view that relates different developments in a variety of countries. The main question addressed by all contributors is what an academic life looks like today, given the social and political consequences of educational expansion. We are particularly interested in the relationship between academic credentials and gender issues, social stratification, political engagement and individual life plans.

In this issue, we ask to what extent being an academic has moved closer to ordinary professional life. We are curious to find out how young academics reconcile their individual life plans, their research interests and career intentions. We want to focus on the living and working conditions of those with an academic training inside academia. We are interested in practices in the lives of today's students, in the realities of writing a $\mathrm{PhD}$ and the promises and pitfalls of an academic life after graduation.

With these questions in mind, we look at the university as a place to realise a special way of living one's life. We expect that academic life, with its higher degrees of freedom, lower expectations of utilising the products of daily work and its persistent cultural traditions, continues to differ from other forms of life. At the same time, we suspect that the idea of an open and unrestrained scientific community has always been an ideology that obscures the real working conditions at universities and colleges. We also assume that, as in any other organisation, envy, inertia and schematic thinking are the order of the day in universities and colleges. At the same time, no other place of work seems to be better suited to thinking beyond the present and developing something new.

We therefore asked our contributors to take a critical and well-founded look at contemporary forms of academic life. We invited researchers of different origins and scientific approaches to reflect on the meaning of academic life today. We are looking forward to a stimulating debate.

\section{The Editorial Team of on_education}

\section{References}

Anderson, R. (2016). University fees in historical perspective. Policy Paper on History and Policy website.

http://www.historyandpolicy.org/policy-papers/papers/university-fees-in-historical-perspective Archibald, R. B., \& Feldman, D. H. (2010). Why does college cost so much? New York: Oxford University Press.

Blossfeld, P., Blossfeld, G., \& Blossfeld, H.-P. (2015). Educational expansion and inequalities in educational opportunity: Long-term changes for East and West Germany. European Sociological Review, 31(2), 144-160.

Boliver, V. (2011). Expansion, differentiation and the persistence of social class inequalities in British higher education. Higher Education, 61(3), 229-242.

Cyranoski, D., Gilbert, N., Ledford, H., Nayar, A., \& Yahia, M. (2011). Education: The PhD factory. Nature, 472, 276-279.

Frank, D. J., \& Gabler, J. (2006). Reconstructing the university: worldwide shifts in academia in the 20th century. Stanford: Stanford University Press.

Frølich, N. Wendt, K., Reymert, I., Tellmann, S. M., Elken, M., Kyvik, S., Vabø, A., \& Larsen, E. H. (2018). Academic career structures in Europe: Perspectives from Norway, Denmark, Sweden, Finland, the Netherlands, Austria and the UK. Oslo: NIFU. 
Labaree, D. F. (2017). A perfect mess: The unlikely ascendancy of American higher education. Chicago: The University of Chicago Press.

Mälzer, M. (2016). Auf der Suche nach der neuen Universität. Die Entstehung der "Reformuniversitäten" Konstanz und Bielefeld in den 1960er Jahren. Göttingen: Vandenhoeck \& Ruprecht.

Michalski, J. H., Cunningham, T., \& Henry, J. (2017). The diversity challenge for higher education in Canada: The prospects and challenges of increased access and student success. Humboldt Journal of Social Relations, 39, 66-89.

Powell, K. (2015). The future of the postdoc: There is a growing number of postdocs and few places in academia for them to go. Nature, 520(7546), 144-147.

Schofer, E., \& Meyer, J. (2005). The worldwide expansion of higher education in the Twentieth Century. American Sociological Review, 70(6), 898-920.

\section{Recommended Citation}

Editorial Team (2018). Academic Lives. On Education. Journal for Research and Debate, 1(3). https://doi.org/10.17899/on_ed.2018.3.0

\section{Download PDF version}

Do you want to comment on the whole issue? Please send your reply to editors@oneducation.net. Replies will be processed like invited contributions. This means they will be assessed according to standard criteria of quality, relevance, and civility. Please make sure to follow editorial policies and formatting guidelines. 